\title{
Making the Case for BYOD Instruction in Teacher Education
}

\author{
Nancy Burns-Sardone \\ Georgian Court University, Lakewood, New Jersey USA \\ sardonen@georgian.edu
}

\begin{abstract}
This paper reports on findings of a bring-your-own device (BYOD) study conducted in a teacher education course. Data was examined for interactions among a community of learners for evidence of preparedness, proficiency, and innovation with smart phones. Findings indicate that preservice candidates $(n=58)$ know how to use their smart phones for personal use, which can influence innovation when designing classroom activities using these devices. Adaptation of smart phones for classroom instruction was met with positive reactions. Only three of the fifty-eight participants $(<5 \%)$ did not own a smart phone. With the growing number of BYOD initiatives in K-12 settings, instructional technology teacher educators may need to include a BYOD module to assure that the candidates they are sending into the classrooms of tomorrow are prepared with requisite technology integration knowledge to meet the curricular needs and learning preferences of K-12 students.
\end{abstract}

Keywords: Teacher Education, BYOD, smart phones, Quick Response Codes

\section{Introduction}

The bring-your-own device (BYOD) phenomenon, which began in the workplace, is finding its way into the K-12 classroom. BYOD simply means the policy of permitting employees to bring personally owned mobile devices (laptops, tablets, and smart phones) to the workplace, and to use those devices to access privileged company information and applications (Bradley, 2011). The BYOD practice was identified in 2009 by Intel Corporation, who recognized the increased tendency among its employees to bring their own devices to work and connect them to the corporate network. Rather than reject the trend, as many organizations initially attempted, Intel's senior leaders were quick to embrace it as a means to cut costs and improve productivity (Harkins, 2013). Since January 2010, the number of employee-owned mobile devices on the job has tripled from 10,000 to 30,000, and by 2014, Intel CISO Harkins expects that 70 percent of Intel's 80,000 employees will be using their own devices for at least part of their job (Harkins, 2013). In 2011,

IT services provider Unisys and a few

Material published as part of this publication, either on-line or in print, is copyrighted by the Informing Science Institute. Permission to make digital or paper copy of part or all of these works for personal or classroom use is granted without fee provided that the copies are not made or distributed for profit or commercial advantage AND that copies 1) bear this notice in full and 2) give the full citation on the first page. It is permissible to abstract these works so long as credit is given. To copy in all other cases or to republish or to post on a server or to redistribute to lists requires specific permission and payment of a fee. Contact Publisher@InformingScience.org to request redistribution permission. software vendors started to participate in this emergent trend. BYOD is making significant inroads in the business world, with about $75 \%$ of employees in high growth markets such as Brazil, Russia, India, UAE, and Malaysia, and $44 \%$ in developed, mature markets such as the United States, Japan, and the European Union are using their own technology at work (Ovum, 2012). 
BYOD is used to describe the same practice applied to students using personally owned devices in education. The practice of bringing your own device to school is growing slower than industry for the same broad reasoning - as a way to reduce organizational costs. To date, school principals increasingly support bring-your-own-device (BYOD) initiatives. Forty-one percent of principals surveyed allowed students to use their own devices in the 2013 school year, while only twentytwo percent did so in 2010. While only ten percent of principals allow full-scale BYOD, this represents an increase from 2010 when just three percent of principals reported the same (Project Tomorrow, 2014).

So, it appears that BYOD in gaining momentum in K-12 school districts. Yet, we must consider if these individuals would want to use their smart phone for learning purposes. Are tomorrow's teachers proficient with smart phones? And lastly, what types of BYOD prototype activities do preservice teachers develop for future students when working on their own? These questions are the focus of this study. Numerous scholars and teachers alike have indicated that opportunities to engage with technology-oriented course materials are vital for preservice teachers' understanding of how to integrate technology in the curriculum, especially after reflecting on that practice (Dawson \& Fichtman, 2007; Pope, Hare, \& Howard, 2005). With the BYOD trend knocking on the doors of school districts that face limited funding, it is important for teacher educators to determine the readiness of their candidates and provide instruction on how to integrate BYOD practices into instruction.

\section{Literature Review}

The BYOD movement has implications for tomorrow's work force, as the employees in highgrowth markets are demonstrating flexible attitudes to working hours, and are incentivized to use their own devices for work as they believe it will get them ahead in their careers. This behavior "will shape not just future patterns of mobility in high-growth markets compared to mature markets, but also dictate which markets, structurally, are going to benefit most from this revolution in how and where we work" (Ovum, 2012, p. 1). Tomorrow's work force is today's K-12 and college students, who have embraced technology as a whole, indicating their daily media exposure close to 11 hours (Rideout, Foehr, \& Roberts 2010). Daily media exposure of children, ages 8-18 includes television (4:29), music/audio (2:31), computers (1:29), videogames (1:13), print (0:38), and movies ( $0: 25)$. Technology, mostly computer-based, has been used in formal instructional settings for over fifteen years. BYOD transits ownership of the devices to students with the expectation that they use their own devices (i.e. smart phones) for learning purposes. Further, educators are urging that technology be integrated more extensively into curricula (NEA, 2008; Project Tomorrow, 2010), and that this infusion be directed toward higher-order thinking skills (Yell \& Box, 2008).

Yet, we must consider if these individuals would want to use their smart phone for learning purposes. When we view studies of students and their technology use, we begin to understand that students want their teachers to "power up" rather than require them to "power down" for learning. Perhaps, then, the timing of the BYOD is correct; students have voiced that want to use technology. But first, we first need to determine if they even own smart phones. The percentage of teenage cell phone users in 2010 was 85 percent (Rideout, Fochr, \& Roberts, 2010). It is this group who is expected to replace their cell phone with a smart phone, with 2013 forecasted smart phone sales expected to double 2011 levels, reaching 880 million units sold (Sangani, 2013). Growth of smart phones for personal use among the teen age sector is revealed in this forecast however, we have to consider the learning effectiveness of students using smart phones/cell phones. To determine this, we look to one research study that revealed that students who used their cell phones on a state test to boil down the main points of the stanzas got 80 percent of the questions about the poem correct. Students taught the same material in the traditional way scored less; 40 percent cor- 
rect (Walling, 2013). Clearly, students are geared up to learn with powerful technology-based devices and initial findings, albeit limited, are positive.

The National Education Association (NEA) has posed the question of whether schools should embrace BYOD in a recent article that outlines positives and challenges of a BYOD program (Chadband, 2012). Proper planning to include training for online safety and security, a borrowing program for students who do not have smart devices, the development of the schools' acceptable use/responsible use policies, and a discussion of ground rules with students and teachers alike. Chandband warns of possible BYOD hazards. When students bring their own devices, cyberbullying and other problems associated with social media may follow. Many students, for example, don't understand how much they should share online, and they could end up posting information that could jeopardize their academic, or even professional, futures (2012).

Yet, the issue of preparing teachers for BYOD technology infusion remains. Not every district has the resources to properly train teachers to use the smart devices (smart phones, tablets, etc.) students will bring in, especially those that have already faced large budget cuts. A BYOD program could save money if implemented properly, but tossing teachers into a BYOD environment without any training wouldn't be very effective (Chadband, 2012). A recent comparative analysis of five high-profile national teacher and technology surveys released between February 2012 and February 2013 comprising over 4,500 in-service teachers reveals an overwhelming use of technology in the curriculum (Pressey, 2013). In terms of professional development to learn how to integrate technology, most teachers cite in-service workshops, self-directed study, online study, other teachers within the district, or from attending seminars, conferences, or conventions as their learning method of choice.

Yet, quality training is not easy to find. In the Bill \& Melinda Gates Foundation (2012) study $(\mathrm{n}=401), 48 \%$ reported the lack of training is the biggest barrier to incorporating technology into their teaching (p. 3). Teachers also reported that they do not get adequate district sponsored training on specific technologies or how to more fully integrate technology into their teaching. Nearly half of survey respondents cited inadequate training as a reason they would not use technology to support their teaching (p. 3). Teachers in schools with mainly lower income students tend to be the least to report receiving formal training from their school or district as to how to effectively incorporate digital technologies into the classroom (p. 56).

In light of limited training opportunities, perhaps one answer lies within teacher education programs to include BYOD training in their curriculum. BYOD training in a teacher preparation program is one idea that can aid in eliminating the existing barrier of a lack of quality training programs to incorporating technology into teaching and learning. Prior research tells us that familial education may equip students to accomplish immediate goals, but it may not be sufficient to be successful in college and beyond (Hoffman \& Vance, 2004). In other words, in the case of teacher preparation, what candidates do with technology to complete tasks like schoolwork may not translate to using similar tools for teaching purposes. Students tend to overstate their computing abilities because they are often bound by what they know how to do, and have no reason to expand beyond those bounds. Three studies provided evidence of such computing deficiencies. Northwest Missouri State University reported that of the 191 students who took an information technology proficiency exam, only two percent mastered it at an 80 percent rate (Hardy, Heeler, $\&$ Brooks, 2006). At a large Midwestern university, results revealed that students' $(n=91)$ perception of their information technology fluency is far greater than actually realized (Wilkerson, 2006). And finally, in a study from Quinnipiac University, freshmen $(n=800)$ reported they learned technology tasks at home with family support, concluding that familial education may equip students to accomplish immediate goals, but it may not be sufficient to be successful in college and beyond (Hoffman \& Vance, 2004). 


\section{The Study}

This case study uses a qualitative approach. Face-to-face observational research allows the researcher to formulate their own version of what is occurring, independent of the participant input. One goal of this method was to diminish the direct input of participants because the results would be limited by participants' knowledge, memory, and ability to convey information clearly and accurately, and, also, by how they wished to be perceived by outsiders such as the researcher. Yet, triangulation of data in an observational study is important to enhance the validity of findings and help to eliminate bias that night result from relying exclusively on one-data collection method (Gall, Borg, \& Gall, 1996). For this reason, an ethnographic content analysis was conducted on the homework assignments that participants completed involving QR codes. This analysis involves the examination of the content of the documents as reflections of social interactions in the culture (Gall et al., 1996, p. 630). The study is limited to a sample of convenience. It is important to state that this study is not about the development of QR codes, (discussed later) but the observations of students when immersed in a specific task using smart phone technology. The QR code in-class lesson was simply used a lens used to observe what the study intended to observe. This study was guided by the following research questions:

1. Would participants want to use their smart phone for learning purposes?

2. Are participants proficient with smart phones?

3. What types of BYOD-based prototype activities do participants develop?

\section{Participants and Setting}

At a small liberal arts college in New Jersey (USA), teacher education students $(n=58)$, ages 2035 , who were enrolled in as required course partook in the activity. Three participants were male and fifty-five female. Course work included research-studies readings in instructional technology, active participation with technology-based tools and materials, and the development of a showcase portfolio using Web Design software. All students except for three had their own smart device. Those three students borrowed a device from another students or the instructor.

\section{Instruments}

Two instruments were used to collect data in this study. The first was a class observation schedule (COS) instrument was used to collect data on student interactions, activities, context, and behavior (See Appendix). This instrument has been used in a variety of studies on effective instruction, resilient and nonresilient students, and effects of technology. The instrument's clear definitions and format enables an observer to achieve accurate descriptions of student processes in classrooms (Waxman \& Pardon, 2005). Scans of whole classroom on-task behavior were systematically conducted between each set of observations with individual students.

The second instrument was a content analysis of participants' QR code homework assignment. Content analysis is a research technique for the objective, systematic, and quantitative description of the manifest content of communication (Berelson, 1952).

\section{Procedure}

Participants were asked to bring their smart phones to class on one specific date during the semester. After a short introduction to QR codes, preservice candidates watched a YouTube video (See Resources) created by a seasoned teacher, who explained the use of QR codes at her school to improve literacy rates. Participants then read a children's story, which was selected from a list of available books and wrote a short book review. A few of the book titles included: Grace for President (2012) by Kelly S. DiPucchio; 14 Cows for America (2009) by Carmen Agra Deedy; and Brothers in Hope: The Story of the Lost Boys of Sudan (2005) by Mary Williams. These se- 
lections were purposeful, giving students who plan to teach young children an opportunity to review books with which they might not be familiar.

Participants were given instructions to download two free APPs from the iTunes store: AudioBoo and $Q R$ Reader and install both on their smart device (See Resources). They were then instructed to record their book review using Audioboo and using the same APP, convert the recording to a QR code. Audioboo allows users to record, playback, post, and share sound files - up to three minutes in length. These recordings are referred to as "boos" and each boo is assigned a unique URL. Participants then printed out the QR code and taped the code to the book that they reviewed. Each QR code was tested by participants to ensure proper functioning.

To collect data on classroom activity, scans for student involvement in their given task were systematically carried out during a 30-minute observation. Following each scan, the observer recorded a sampling of individual student behavior in 30-second intervals using the COS instrument. Five students were observed for five minutes in each of the four sections of this course. The three students who did not own a smart phone partnered with a peer, who shared their smart phone with them to complete the lesson tasks.

Debriefing ensued after the task, where the researcher asked participants to report their opinions of classroom uses of QR codes and solicit their ideas for classroom use. Participants were then given one homework assignment asking them to develop an idea for QR code use in an educational setting and to provide and explanation of the idea and the way it aims to help students in their learning.

\section{Data Analysis}

Two modes of inquiry were used in this study. First, data collected using the COS instrument was tallied and summarized according to COS instrument wording. This qualitative study includes descriptive analysis derived from COS data.

A content analysis was conducted on the homework assignments that participants completed involving QR codes. The assignments were evaluated based on a classification system based on the Substitution, Augmentation, Modification and Redefinition (SAMR) model (Pnuentedura, 2013) of technology, which indicates different levels by which technology integration can be employed by teachers in the classroom curriculum. The first two stages represent enhancements made to instruction using technology tools. In the substitution stage, technology acts as a direct tool substitute, with no clear functional change. The augmentation stage is where technology acts as a direct tool substitute, with functional improvement over the prior method used. The following two stages represent transformation. The modification stage requires a significant task redesign, with clear evidence that the instructional designer (i.e., teacher) has given thought to the task at hand and redesigned the task to evoke greater learning outcomes. The last stage, redefinition, is when technology allows for the creation of new tasks, previously inconceivable.

To provide an example, in one study, "Using Laptops to Facilitate Middle School Science Learning: The Results of Hard Fun" conducted in the state of Maine (Berry \& Wintle, 2009), students were already at the augmentation using interactive tools for concept exploration and visualization. Teachers moved students in the experimental to the next stage, modification, when students learned how to narrate animations for their final projects. Post-assessment effect size of 0.6 was reported where the experimental group spent more time on-task and their academic achievement was higher than the control group. Retention assessment was also higher in the experimental group, reporting an effect size of 1.42 (Berry \& Wintle, 2009). 


\section{Results}

Research question one, "Would participants want to use their smart phone for learning purposes"? was answered based on two indicators. The first was the responses received when asked to bring in their own smart phones for a specific class session. No negative responses were indicated or questions about the appropriateness of using their smart phones for learning purposes were received. The second indicator was the type of information students shared during the debriefing session. Not one response revealed unreasonableness to provide their own smart phone for learning purposes. Perhaps students are so used to using the smart phones for personal use, the lines have become blurred. Perhaps they see learning as personal.

In an effort to answer research question two, "Are candidates proficient with smart phones?" classroom observations of the participants were conducted. The group was observed as attentive during the 15 minute teacher presentation on the definition of, classroom applications of QR codes, and guidelines for QR code development. The group was then observed as actively participating in the given task, described in the procedures section above. Some participants verbally stated hesitancy when recording their book review. In this situation, the instructor intervened explaining that although they may be embarrassed to record, in reality, no one was actively listening as other students were busy with portions of the same assignment. Otherwise, little need for teacher management was observed. No off-task behavior was noted, rather, participants were ontask with enthusiasm. A few other comments were noted: the speed and proficiency at which participants proceeded to download required APPs was remarkable. Downloading procedures were not taught by the instructor, although she asked if anyone needed help. All but three students knew how to do this. Based on little need for assistance and the successful completion of downloading the required APPs, recording an oral book review using one specific APP, generating a QR code that became the pathway to the recorded review, figuring out how to print the associated QR code, and reading the QR code with the other required APP, it was determined that candidates were proficient with smart phones.

A content analysis was performed to answer the third research question, "What types of BYODbased prototype activities do preservice teachers develop for future students when working on their own (QR code homework assignments)? The content analysis of the QR code homework assignments revealed some inventiveness on the part of participants'. Using the SAMR classification system of technology integration (Pnuentedura, 2013), it was determined that most of the created activities aimed to enhance the learning experience for students (substitution or augmentation) rather than through a transformation of the learning experience (modification and redefinition) as seen in Table 1. This was expected, as ninety-nine percent of participants had not created a QR code prior to this training nor knew how to use them for teaching and learning purposes. Table 1 also contains a rationale as to how each example fits in each of the SAMR categories.

\begin{tabular}{|c|c|c|l|}
\hline \multicolumn{3}{|c|}{ Table 1. Classroom Uses for QR Codes } \\
\hline Model & $\begin{array}{c}\text { Number of As- } \\
\text { signments } \\
\text { Of Same Type }\end{array}$ & Example & \multicolumn{1}{c|}{ Description of Example } \\
\hline Substitution & 25 & $\begin{array}{l}\text { Science: } \\
\text { Creating } \\
\text { Intrigue }\end{array}$ & $\begin{array}{l}\text { Each fourth grade student is given a unique QR code } \\
\text { as their assigned topic for science class. The QR code } \\
\text { contains the assigned topic (i.e. Oak Trees) and re- } \\
\text { search guidelines. They are told not to share their } \\
\text { topics until they present their information to the class. } \\
\text { Rationale: In this example, no functional change was } \\
\text { made. Students might be more intrigued by the QR } \\
\text { code but the function of distributing science topics is } \\
\text { the same. }\end{array}$ \\
\hline
\end{tabular}




\begin{tabular}{|c|c|c|c|}
\hline Augmentation & 35 & $\begin{array}{l}\text { Format } \\
\text { Change: } \\
\text { Math Vid- } \\
\text { eos }\end{array}$ & $\begin{array}{l}\text { A video using free Web-based program, Screencast- } \\
\text { O-Matic was created depicting place value and up- } \\
\text { loaded to YouTube. Third grade students would use } \\
\text { the QR code that links to this video as a guide when } \\
\text { completing a homework assignment on the same } \\
\text { topic. } \\
\text { Rationale: In this example, a functional change was } \\
\text { made substituting the teacher's real-time lecture with } \\
\text { an archived copy of the lecture. }\end{array}$ \\
\hline Modification & 5 & $\begin{array}{l}\text { Self Effi- } \\
\text { cacy: } \\
\text { Tic-Tac- } \\
\text { Toe }\end{array}$ & $\begin{array}{l}\text { A nine square grid, consisting of QR codes. Each } \\
\text { code is unique containing a grammatically incorrect } \\
\text { sentence. Each third grade student plays as the "X" } \\
\text { player. The teacher is the "O." Students read the } \\
\text { code, and then on a piece of paper, correct the sen- } \\
\text { tence. They then approach the teacher with their cor- } \\
\text { rection and get a slip of paper indicting the correct } \\
\text { sentence structure. They evaluate their own work, } \\
\text { looking for a match. If no match, then an "O" is } \\
\text { placed in that square. If a match, student places an } \\
\text { "X." Play continues. } \\
\text { Rationale: In this example, a transformational } \\
\text { change was made where students are responsible for } \\
\text { self-evaluation rather than teacher corrections. }\end{array}$ \\
\hline Redefinition & 3 & $\begin{array}{l}\text { Math: } \\
\text { Estimation } \\
\text { Skills }\end{array}$ & $\begin{array}{l}\text { Second grade students would practice their estimation } \\
\text { skills when looking at full candy jars. The accompa- } \\
\text { nied QR code reveals the number of candy contained } \\
\text { in each jar. Students can easily check their own work } \\
\text { and practice their estimation skills on their own. Sec- } \\
\text { ond graders would be encouraged to come up with } \\
\text { their own examples and place on a community board } \\
\text { in class so others can practice their estimation skills } \\
\text { as well. } \\
\text { Rationale: In this example, a transformational } \\
\text { change was made where students creating instruc- } \\
\text { tional content to share with their peers. }\end{array}$ \\
\hline
\end{tabular}

During debriefing, some participants revealed concern about K-12 student use of smart phones in the classroom, with some concerned about them as a hindrance to teaching and learning. This view is pragmatic and shared by principals surveyed who haven't entirely resolved concerns - 77 percent said safety and district liability remain an issue, and 70 percent said student equity in device access is important (Project Tomorrow, 2014). Other participants voiced the benefit of having smart phones available to use as an instructional tool to use tied to curriculum standards. Debriefing further discovered that participants liked learning how QR codes could be adapted for instructional purposes that they had not considered prior to this training. Not one response revealed unreasonableness to provide their own smart phone for learning purposes. Perhaps students are so used to using the smart phones for personal use, the lines have become blurred. Perhaps they see learning as personal. When prompted, they offered their assignment ideas to include an outdoor scavenger hunt to collect specimens for a science class, a surprise way to assign the day's vocabulary words, as a homework aid, and an overall intriguing method of instruction to keep students engaged. Although the vast majority of the participants knew the mechanics of their smart phones (downloading APPS, using APPs, etc.) and for personal use, ninety-nine percent did not know how to integrate smart phone use for learning purposes prior to this lesson. 
Mechanical knowledge of smart phones can influence innovation when designing classroom activities using them in BYOD situations.

Consideration of students without smart phones is important in teaching as BYOD programs could increase the digital divide that earlier one-to-one initiatives were meant to narrow (Chadband, 2012). Student-to-student interactions were observed and the essence of those interactions consisted of questions asked to one another about the task at hand. There was as small number of participants who did not have a smart device and they were not familiar with the phone's mechanics. These participants watched and learned and their peers offered them their smart phones to them to complete the learning tasks. Inexperienced smart phone users were guided by the more experienced participants.

\section{Conclusion}

More and more, schools claim that they cannot afford to purchase one-to-one digital learning devices but could fill the gap for students whose families cannot afford such purchases. "Quite simply, BYOD policies are public schools' last best chance to make the needed immediate leap to a digital learning environment" (Costa, 2013, p.8). Many educators are coming around to the idea that since these devices are already in schools, they should use them as learning tools rather than treating them as a problem (Sangani, 2013). Yet, two main reasons prevent parents from buying smart phones for their children; affordability and lack of control. Many teachers share these concerns and hold the view that mobile phones are disruptive to education. And then there are other teachers who have fully embraced BYOD. In a recent article, two middle school teachers who use smart phone in their classrooms offer this advice, "Really, the word "smartphone" is a misnomer-at least as we see it. Of the myriad functions that our smart phones contain, we use the "phone" part the least. We use it as a computer. We use it as a library. The same is true for most of our students" (Passanisi \& Peters, 2013).

BYOD policies require internal management, and when facilitated properly, are keys to making a one-to-one environment a reality. When students bring their own devices to school for educational purposes, it frees up districts' to provide devices for only those who cannot provide devices for themselves, which is within the reach of every district (Costa, 2013) and this view is shared by others (Sangani, 2013). With the introduction of management controls and rules, along with teacher and student education of how to use these mobile tools for learning, there is promise and can set today's U.S. children on the same path as that in emerging and high-growth markets. In addition, BYOD requires that students be educated about online safety and security Further, BYOD programs can be successful when partnered with robust professional development for teachers that extends beyond technical skills to encompass critical thinking and digital literacy (Chadband, 2012).

Teacher educators, in general, and specifically those who teach instructional technology need to rethink the message associated with teaching this type of course in a face-to-face format and computer lab. The computer lab format conveys the idea that learning with technology in placedriven, rather than the correct association of a ubiquitous classroom tool that needs to be available at any given moment for teaching and learning purposes. Technology integration has become the responsibility of the teacher, not a 'special' teacher (i.e., computer teacher). As such, classroom teachers need to have resources for teaching and learning within close proximity, meaning the classroom where that learning is taking place at the time it is taking place.

Participants were adaptable in using their personal devices for professional purposes, whereas past research studies have explained that students entered college with just enough computing skill to accomplish immediate goals (Hoffman \& Vance, 2004). It appears that constant use of smart phone for personal use may have expanded participants' perceived usefulness of said de- 
vices. It could be that proximity to smart phones and the like have increased familiarity and built users' confidence. User confidence may help explain the willingness that was noted to use personal devices for professional purposes, expanding beyond the earlier observed bounds. This is viewed a bonus for teacher education programs. Instead of spending vital class time on learning the nuances and mechanics of smart phones, instructors can spend time teaching about the pedagogy of learning with these smart devices as well as teaching how to design instruction using smart phones in ways that are meaningful to today's students.

\section{References}

Berelson, B. (1952). Content analysis in communications research. Glencoe, IL: Free Press.

Berry, A., \& Wintle, S. (2009). Using laptops to facilitate middle school science learning: The results of hard fun. Center for Education Policy, Applied Research, and Evaluation, University of Southern Maine. Retrieved from http://maine.gov/mlti/resources/ScienceLearning.pdf

Bill \& Melinda Gates Foundation. (2012). Innovation in education: Technology \& effective teaching in the U.S. Seattle, WA: Bill \& Melinda Gates Foundation.

Bradley, T. (2011, December 20). Pros and cons of bringing your own device to work. PCWorld. Retrieved from http://www.pcworld.com/article/246760/pros_and_cons_of_byod_bring_your_own_device_html

Bruff, D. (2012). The scholarship of teaching and learning (SoTL). Vanderbilt Center for Teaching and Learning. Retrieved from http://cft.vanderbilt.edu/teaching-guides/reflecting/sotl/

Chadband, E. (2012, July 19). Should schools embrace "bring your own device"? National Education Association. Retrieved from http://neatoday.org/2012/07/19/should-schools-embrace-bring-your-owndevice/

Costa, J. (2013, April). Digital learning for all, now. Education Digest, 78(8), 4-9.

Dawson, K., \& Fichtman, N. (2007). When curriculum-based technology-enhanced field experiences and teacher inquiry coalesce: An opportunity for conceptual change. British Journal of Educational Technology, 38(4), 656-667.

Devlin-Scherer, R., \& Sardone, N. (2013). Collaboration as a form of professional development: Improving learning for faculty and students. College Teaching, 61(1), 30-37.

Gall, M., Borg, W., \& Gall, J. (1996). Educational research. White Plains: Longman.

Hardy, C., Heeler, P., \& Brooks, D. (2006). Are high school graduates technologically ready for postsecondary education? Journal of Computing Sciences in Colleges, 21(4), 52-60.

Harkins, M. (2013). Mobile: Learn from Intel's CISO on securing employee-owned devices. Information Security Media Group. Retrieved from http://www.govinfosecurity.com/webinars/mobile-learn-fromintels-ciso-on-securing-employee-owned-devices-w-264

Hoffman, M., \& Vance, D. (2004). Computer literacy: What students know and from whom they learned it. Association of Computing Machinery. Proceedings from 36th SIGCSE Technical Symposium on Computer Science Education, 37(1), 356 - 360.

National Education Association (NEA). (2008). Access, adequacy, and equity in education technology: Results of a survey of America's teachers and support professionals on technology in public schools and classrooms. Washington, DC: NEA.

Ovum. (2012, October). Multi-market BYOD survey results: Employee behaviour and attitudes toward mobile device usage at work. Retrieved from http://www.logicalis.com/news-andevents/news/logicalis-white-paper-byod.aspx\#.ULYlm9OLL31 
Passanisi, J., \& Peters, S. (2013, December 10). The powerful computer in your pocket: Using smart phones in the classroom. EdWeek. Retrieved from http://www.edweek.org/tm/articles/2013/12/10/fp_passanisi_peters_smartphone.html

Pnuentedura, R. (2013, July). SAMR: An EdTech quintet perspective. Retrieved from http://www.hippasus.com/rrpweblog/archives/2013/07/29/SAMRAnETQPerspective.pdf

Pope, M., Hare, D., \& Howard, E. (2005). Enhancing technology use in student teaching: A case study. Journal of Technology and Teacher Education, 13(4), 573-618.

Pressey, B. (2013). Comparative analysis of national teacher surveys. New York: The Joan Ganz Cooney Center at Sesame Workshop. Retrieved October 27, 2013 from http://www.joanganzcooneycenter.org/wpcontent/uploads/2013/10/jgec teacher_survey analysis_final.pdf

Project Tomorrow. (2014). The new digital learning playbook: Understanding the spectrum of students' activities and aspirations. Retrieved from http://www.tomorrow.org/speakup/pdfs/SU13StudentsReport.pdf

Project Tomorrow. (2010). Creating our future: Students speak up about their vision for 21st century learning. Irvine, CA: Project Tomorrow. Retrieved from www.tomorrow.org/speakup/pdfs/SUNationalFindings2009.pdf

Rideout, V. J., Foehr, U. G., \& Roberts, D. F. (2010, January). Generation M2: Media in the lives of 8- to 18-year-olds. Menlo Park, Calif.: Henry J. Kaiser Family Foundation.

Sangani, K. (2013). BYOD to the classroom. Engineering \& Technology. 8(3), 42-45.

Walling, D. (2012). The tech-savvy triangle. TechTrends: Linking Research \& Practice to Improve Learning, 56(4), 42-46.

Waxman, H. C., \& Pardon, Y. N. (2005). The uses of classroom observations schedule to improve classroom instruction. In H. C. Waxman, R. Tharp, \& S. Hilberg. Observational research in U.S. classrooms (pp. 72-96). New York: Cambridge University Press.

Wilkerson, K. (2006). Students' computer literacy: Perception versus reality. Delta Pi Epsilon Journal, $48(2), 108-120$.

Yell, M., \& Box, J. (2008). Embrace the future: NCSS and P21. Social Education, 72 (7), 347-349.

\section{Resources}

AudioBoo APP- $\underline{\text { https://itunes.apple.com/us/app/audioboo/id305204540 }}$

QR Codes in the Classroom - http://www.youtube.com/watch?v=5LT3GQPqVew

QR Reader APP- https://itunes.apple.com/us/app/qr-reader-for-iphone/id368494609?mt=8\&ign-

$\underline{\mathrm{mpt}=\mathrm{uo} \% 3 \mathrm{D} 2}$ 


\section{Appendix}

I. Total Class Engagement: Scan Time: Total Number of Students: Total number of students off-task:

II. Strategy Used: Whole Group Work Alone Small Group Seat Work Listening Organizing Tell Read Aloud Demo

III. Classroom Observation Schedule: Instructor Asking Qs Discussion Observing Subject:

\section{A. Interactions}

\begin{tabular}{|l|l|l|l|l|l|}
\hline 1.No interaction/independence & 1 & 2 & 3 & 4 & 5 \\
\hline 2. With instructor - Instructional & & & & & \\
\hline 3. With instructor - Managerial & & & & & \\
\hline 4. With instructor - Social, Personal & & & & & \\
\hline 5. With other students - instructional & & & & & \\
\hline 6. With other students - Managerial & & & & & \\
\hline 7. With other students - Social, Personal & & & & & \\
\hline 8. Other & & & & & \\
\hline
\end{tabular}

\section{Biography}

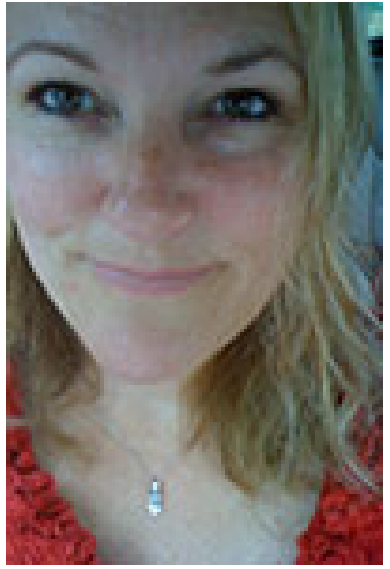

Nancy B. Sardone received her Ph.D. in Business Education from New York University (USA). She holds a Bachelor of Science degree from University of Massachusetts at Amherst in Resource Economics and a Master's in Business Education from New York University. She is currently an Assistant Professor and former chairperson in the Teacher Education Department at Georgian Court University, Lakewood, New Jersey. She teaches courses in instructional design and instructional technology for inclusive classrooms. Her research interests include curriculum and instruction. Topics of published articles and presentations are assistive technology, ePortfolios, game-based learning, and development of IT fluency. 